\title{
DESKRIPSI KERJA KEPALA CABANG UNTUK OPTIMALISASI KINERJA KOPERASI SYARIAH
}

\author{
Hasnil Hasyim \\ Sekolah Tinggi Agama Islam Al-Hidayah \\ Hasnil.alhidayah@gmail.com
}

\begin{abstract}
ABSTRAK
Salah satu indikator pertumbuhan ekonomi nasional adalah dengan meningkatnya usaha sektor riil. Koperasi syariah merupakan salah satu lembaga keuangan yang concern terhadap pembiayaan sektor UKMK (usaha mikro dan kecil menengah) dan berpihak kepada ekonomi kerakyatan. Dalam penelitian ini menggunakan metode kualitatif yang tidak memerlukan pengetahuan mendalam akan literatur yang digunakan dan kemampuan tertentu. Eksistensi Koperasi syariah sangat dibutuhkan untuk pemberdayaan ekonomi masyarakat kecil sehingga perlu didukung oleh berbagai kalangan. Agar koperasi Syariah tumbuh dan berkembang serta keberadaannyanya berjalan dengan baik,maka dibutuhkan kepala cabang yang memiliki kemampuan dan kompetensi di bidangnya. Untuk itu, deskripsi kerja kepala cabang sangat dibutuhkan sebagai acuan standar dalam bekerja sehingga visi dan misi koperasi syariah akan tercapai yaitu mensejahterakan dan memakmurkan seluruh anggotanya.
\end{abstract}

\section{A. PENDAHULUAN}

Karyawan atau pegawai merupakan asset yang paling berharga bagi organisasi bisnis perusahaan. Untuk mencapai tujuan visi dan misi perusahaan maka diperlukan karyawan atau pegawai yang kompeten dan ahli di bidangnya. Pengukuran kinerja pegawai atau karyawan memang peranan penting dalam dunia bisnis. ${ }^{1}$ Istilah "the right man on the right place" yaitu menempatkan seseorang sesuai dengan keahlian sangatlah penting sehingga tujuan koperasi tercapai yaitu memakmurkan dan mensejahterakan seluruh anggota koperasi.

\footnotetext{
${ }^{1}$ Syahruddin Kadir. (2019). Pengembangan Pengukuran Kinerja dengan Pendekatan Mashlahah Score Card. Ad-Deenar: Jurnal Ekonomi dan Bisnis Islam, 03(01). hlm. 76.
}

Karyawan atau pegawai yang dimaksud adalah orang yang bekeerja pada pemerintah, perusahaan tertntu, atau Lembaga-lembaga tertentu, yang bertujuan untuk mendapatkan atau menghasilkan upah atau balasan lain yang sepadan dengan ketentuan yang berlaku, yang intinya karyawan merupakan orang yang bekerja Cepeda orang lain ataupun pihak lain sesuai dengan bidang yang digeluti. ${ }^{2}$

Unrtuk mewujudkan karyawan yang memiliki disiplin dan kinerja yang tinggi diperlukan peran yang besar dari pribadi pemimpin suatu perusahaan,

${ }^{2}$ Rahendra Maya. (2018). Pemikiran AsSa'di tentang Kriteria Pegawai Profesional (Studi Terhadap Q.S. Al-Qashash [28]: 26, Hadits-hadits Terkait. dan Kajian Lain). Ad-Deenar: Jurnal Perbankan Syariah, 02(01). hlm. 5. 
Doi: 10.30868/ad.v4i01.755

Lembaga, atau organisasi ${ }^{3}$ dimana

kinerja merupakan usaha untuk merencanakan dan mengontrol proses pengelolaan pekerjaan sehingga dapat dilaksanakan sesuai tujuan yang telah ditetapkan. ${ }^{4}$

Lembaga keuangan khususnya koperasi juga perlu menerapkan profesiionalitas karyawan dalam bekerja dengan menerapkan aturan reward dan punishment yaitu adanya penghargaan dan hukuman dalam bekerja baik pada level top management maupun low management. Hal ini dimaksudkan untuk memotivasi karyawan dan akan timbul semangat atau tantangan dalam bekerja.

Untuk mencapai tujuan perusahaan atau lembaga keuangan khususnya koperasi maka perlu dibuatkan indikator atau target (key performance indikator) oleh atasan yang bersangkutan dan deskripsi kerja sehingga arahan dan capaian akan mudah terwujud.

Kepala Cabang/Manager adalah seseorang yang bertanggung jawab terhadap seluruh operasional kegiatan

${ }^{3}$ Nunung Ghoniyah dan Masurif. (2011). Peningkatan Karyawan Melalui Kepemimpinan, Lingkungan Kerja dan Komitmen. JDM: Jurnal Dinamika Manajemen, 2(2). hlm. 120.

4 Sri Hindah Pudjihastuti dan Haves Ardhani. (2013). Optimalisasi Kinerja Pegawai Badan Kepegawaian Daerah Kota Semarang. Ekobis, 14(2). hlm. 62. koperasi. Mlanager juga harus memahami seluruh aspek operasional dari segi marketing, keuangan, operaional, legalitas maupun hal lainnya yang berkaitan dengan kegiatan koperasi.

\section{B. PEMBAHASAN}

Dalam dunia bisnis kinerja dapat membantu manajer dalam memonitor implementasi strategi bisnis itu sendiri dengan cara membandingkan antara hasil aktual dan tujuan. Hal ini, kinerja sebagai pengukur pengelolaan bisnis yang secara etis dan mendasar. Konsep keseimbangan pengukuran yang dilakukan dengan dua hal, yaitu; metode grafik dan numerik.

Kinerka disebut juga perpormence, yaitu sebagian atau seluruh tindakan dan aktifitas dari suatu lembaga pada suatu periode tertentu, ${ }^{5}$ Sarifudin menyatakan, bahwa kinerja merupakan melaksanakan seluruh kegiatan yang dilakukan oleh seseorang, baik berupa administrasi, bimbingan terhadap karyawan, kedisiplinan, dan penilaian terhadap hasil pekerjaan dari karyawan tertentu. ${ }^{6}$

Kerja kepala cabang adalah manajemen yang memanage bawahannya

\footnotetext{
${ }^{5}$ Syahruddin Kadir. (2019). hlm. 79.

${ }^{6}$ Sarifudin. (2019). Implementasi Supervisi Kepala Sekolah terhadap Kinerja Guru dalam Upaya Meningkatkan Kualitas Pembelajaran di Madrasah Ibtidaiyah Negeri (MIN) Kota Bogor. Islamic Management: Jurnal Manajemen Pendidikan, 02(01). hlm. 59-60.
} 
Doi: 10.30868/ad.v4i01.755

agar bisa saling bersinergi untuk menuju hasil yang optimal yang perannya sangat dibutuhkan. sehingga produktivitas kerja karyawan disetiap kantor cabangnya akan berkaitan dengan bagaimana cara kerja yang diterapkan. ${ }^{7}$

Berikut deskripsi kerja level kepala cabang/manager di koperasi syariah:

\section{Mengembangkan Pasar/Anggota Baru}

Marketing merupakan ujung tombak perusahaan dalam hal ini adalah koperasi. Mekanisme bisnis di lembaga keuangan adalah bagaimana pembiayaan yang diberikan kepada anggota berjalan dengan baik dari segi usaha dan sistem pembayarannya (nanti akan dibahas tentang analisis pembiayaan dengan 5C), jika sistem pembayaran berjalan lancar maka operasional lembaga keuangan tersebut akan berjalan dengan sehat pula.

Untuk mulai mencari anggota baru dapat berupa referensi atau informasi dari anggota lama karena beliau memahami karakter dan kompetensi atau mencari anggota baru dapat pula dengan memberikan pembiayaan yang kecil terlebih dahulu.

Untuk menghindari terjadinya resiko pembiayaan bermasalah, koperasi memberikan aturan untuk menjadi

${ }^{7}$ Betrik J Hutapea, Mesran, Siti Nurhabibah. (2018). Sistem Pendukung Keputusan Pemilihan Kepala Cabang Terbaik Bank Sumut dengan Menerapkan Metode Vikor. KOMIK: Konferensi Nasional Teknologi Informasi dan Komputer, 02(01). hlm. 185. anggota baru harus memiliki simpanan pokok dan wajib, sehingga jika terjadi pembiayaan bermasalah dapat diambil dari simpanan tersebut.

\section{Merekrut dan Memberhentikan Karyawan atau Pegawai}

Kepemimpinan merupakan tulang punggung pengembangan organisasi karena tanpa kepemimpinan yang baik akan sulit untuk mencapai tujuan organisasi. ${ }^{8}$

Tugas kepala cabang/manager selanjutnya adalah merekrut dan memberhentikan karyawan. variabel lingkungan kerja berpengaruh positif signifikan pada kinerja karyawan. Informasi sistem rekrutmen karyawan dapat via media sosial ataupun media lainnya sehingga efektif terjangkau oleh seluruh masyarakat. Syarat dan kompetensi calon karyawan sesuai dengan pekerjaan yang akan dia hadapi dan sesuai dengan permintaan user yang bersangkutan.

Karyawan yang telah diterima perusahaan ataupun koperasi diberikan masa percobaan selama 3 atau 6 bulan untuk melihat kinerja dan produktivitas sesuai dengan target yang diberikan. Jika telah melewati masa 3 atau 6 bulan maka perusahaan berhak memutuskan apakah diterima sebagai karyawan tetap,

\footnotetext{
${ }^{8}$ Nunung Ghoniyah dan Masurif. (2011).
} hlm. 120 . 
Doi: 10.30868/ad.v4i01.755

karyawan kontrak ataupun diperpanjang masa percobaannya.

Begitu pula sebaliknya jika ada karyawan atau pegawai yang tidak sesuai dengan aturan perusahaan atau melakukan tindakan negatif yang dapat merugikan eksistensi perusahaan ataupun pribadi dirinya maka manager berhak melalukan tindakan tegas yakni berupa memberikan surat peringatan ataupun sanksi pemecatan.

\section{Memastikan Kegiatan Operasional Berjalan dengan Baik}

Manager harus memastikan kegiatan operional berjalan dengan baik, maksudnya adalah apabila ada salah seorang karyawan tidak masuk maka manager dapat menggantikan posisi karyawan tersebut dan kegiatan operional berjalan seperti biasanya, misal bagian teller tidak masuk dan pada hari tersebut terdapat penarikan uang simpanan maka manager dapat menggantikan posisi teller tanpa harus menunda penarikan simpanan anggotanya.

\section{Menentukan Plafond}

\section{Pembiayaan/Komite Pembiayaan}

Untuk menentukan disetujui atau tidaknya pembiayaan maka komite pembiayaan harus berjalan dengan baik. Komite pembiayaan adalah rapat internal koperasi untuk menentukan apakah pembiayaan disetujui atau tidak yang terdiri dari unsur kepala cabang/manager, marketing dan keuangan.

Secara tehnis bagian marketing mengajukan calon anggota baru setelah melakukan survey usaha dan wawancara pada calon anggota,kemudian dilakukan analisis pembiayaan berdasarkan 5 (caracter, capabilitas, capital, condition, colateral) dan analisis keuangan calon anggota.

Setelah itu dilakukan komite pembiayaan dan peran dari kepala cabang adalah menentukan apakah pembiayaan tersebut disetujui atau tidak dan berapa besaran plafond pembiayaan jika hasil dari komite pembiayaan tersebut dinyatakan calon nasabah layak diberikan pinjaman maka kepala cabang memberikan rekomendasi dalam bentuk tanda tangan.

Perlu diketahui pula bahwa plafond wewenang kepala cabang untuk memberikan persetujuan pinjaman diatur kepada kebijakan koperasi syariah masing masing maksudnya adalah misalnya maksimal plafond untuk persetujuan pembiayaan oleh kepala cabang 50 juta, jika ada calon anggota mengajukan pembiayaan lebih dari 50 juta maka kepala cabang atau manager harus meminta persutujuan dari ketua pengurus koperasi syariah tersebut.

\section{Menjalin Kerjasama dengan Pihak Luar Ex. Bank, Corporate}


Sumber modal dari Koperasi syariah salah satunya adalah pembiayaan dari Bank Syariah. Kepala Cabang atau manager harus memiliki jaringan atau relasi bisnis yang luas di perbankan syariah yang ada. Sumber Modal atau pinjaman yang diberikan merupakan indikator kesehatan koperasi untuk meningkatkan likuiditas dan sustainanble bisnis.

Koperasi syariah dalam mengadakan kerjasama pembiayaan harus dengan perbankan syariah pula karena sistem koperasi syariah harus terhindar dari transaksi maysir, ghoror dan riba. Ada beberapa koperasi syariah melakukan kerjasama pembiayaan dengan perbankan konvensional yang menerapkan sistem bunga dengan alasan darurat, maka hal ini perlu ditegaskan bahwa sumber modal yang masuk ke koperasi syariah haruslah halal dan pembiayaan yang diberikan juga harus halal dan sesuai dengan fatwa dewan pengawas syariah.

Kepala cabang atau Manager juga harus mengambil peluang dana yang diberikan perusahaan dalam bentuk corporate social responsibility (tanggung jawab perusahaan) kepada lingkungan sekitarnya. Perusahaan bisnis menganggarkan $10 \%$ atau $20 \%$ dari keuntungan atau laba perusahaan selama setahun untuk pemberdayaan ekonomi masyarakat sekitarnya. Konsep dan ide pemberdayaan ekonomi dapat berupa koperasi syariah untuk pemberian modal usaha UMKM (usaha mikro kecil dan menegah) yang dapat didirikan dekat dengan lingkungan perusahaan sehingga sasaran dan tujuan perusahaan tercapai. Perusahaan bisnis memberikan pinjaman biasanya dalam bentuk dana hibah atau zakat perusahaan.

\section{Membuat Rancangan Anggaran Biaya Tahunan}

Kepala cabang atau manager juga harus memiliki kompetensi dalam keuangan dalam hal ini adalah budgeting atau anggaran. Agar penilaian kesehatan lembaga keuangan lebih baik maka salah satu indikatornya BOPO (Biaya Operasional dan Pendapatan Operasional) harus digunakan seefisien mungkin, untuk itu fungsi budgeting atau anggaran harus diperhatikan. Pembuatan anggaran harus dikoordinasikan dengan seluruh bagian (marketing, keuangan dan operasional) agar penggunaannya sesuai dengan realisasi yang dicanangkan bersama sama. RAB atau rencana anggaran biaya dilakukan pada akhir tahun utk realisasi tahun berikutnya. Dengan melakukan anggaran biaya maka kepala cabang atau manager dapat mengestimasi capaian pendapatan yang harus direalisasi selama sebulan sehingga realisasi pendapatan lebih besar daripada biaya selama satu bulan,begitu pula 


\section{Doi: 10.30868/ad.v4i01.755}

untuk bulan selanjutnya. Kepala cabang harus memperhatikan penggunaan biaya yang besar seperti sewa kantor ataupun pemberikan THR pada karyawan, untuk mnghindarkan terjadinya defisit maka bagian keuangan dapat melakukan penyusutan biaya sehingga tidak terjadi biaya yg besar pada bulan tersebut

\section{Menjaga Likuiditas BMT}

Likuiditas adalah kemampuan koperasi syariah atau lembaga keuangan dalam membayar seluruh kewajibannya. Dalam Lembaga keuangan perlu adanya dana mengendap atau cash untuk mencadangkan jika ada anggota menarik simpanannya dalam bentuk simpanan tabungan ataupun simpanan berjangka (deposito). Besarnya dana mengendap adalah 30\% dari seluruh Dana Pihak Ketiga (Tabungan dan Deposito) yang harus ada mengendap di Koperasi. Kepala cabang dan keuangan harus memperhatikan cashflow keuangan dan jatuh tempo deposito dari anggota, sehingga likuiditas lembaga keuangan berjalan dengan baik.

\section{Memberikan Motivasi Karyawan}

Kepala cabang atau manager harus dapat memberikan motivasi dan arahan kepada karyawannya. Setiap karyawan dalam bekerja dapat mengalami kejenuhan karena rutinitas pekerjaan yang dihadapi selama beberapa bulan ataupun tahun, maka untuk menghindari hal tersebut kepala cabang harus mampu memberikan motivasi ataupun arahan sehingga timbul semangat baru untuk karyawan. Kepala cabang yang baik dapat memposisikan dirinya kapan bisa berupa kawan ataupun sebagai atasan, sehingga tidak ada jarak antara atasan dengan bawahan.

\section{KESIMPULAN}

Kepala cabang atau Manager harus memiliki skill dan kompetensi yang baik dalam memimpin lembaga keuangan ataupun Koperasi Syariah. Untuk mencapai target ataupun misi dan visi perusahaan maka perlu dibuatkan deskripsi kerja kepala cabang sehingga target atau sasaran koperasi syariah akan mudah terwujud. Diantara visi dan misi koperasi syariah adalah memakmurkan dan mensejahterakan para anggotanya. Berbagai lembaga sertifikasi telah melalakukan pelatihan dan training untuk meningkatkan kapasitas kepala cabang atau manager sesuai dengan standar keahliannya di bidang marketing, keuangan dan operasional.

\section{DAFTAR PUSTAKA}

Syahruddin Kadir. (2019). Pengembangan Pengukuran Kinerja dengan Pendekatan Mashlahah Score Card. Ad-Deenar: Jurnal Ekonomi dan Bisnis Islam, 03(01).

Rahendra Maya. (2018). Pemikiran AsSa'di tentang Kriteria Pegawai 
Doi: 10.30868/ad.v4i01.755

Profesional (Studi Terhadap Q.S. AlQashash [28]: 26, Hadits-hadits Terkait. dan Kajian Lain). $A d$ Deenar: Jurnal Perbankan Syariah, 02(01).

Sarifudin. (2019). Implementasi Supervisi Kepala Sekolah terhadap Kinerja Guru dalam Upaya Meningkatkan Kualitas Pembelajaran di Madrasah Ibtidaiyah Negeri (MIN) Kota Bogor. Islamic Management: Jurnal Manajemen Pendidikan, 02(01).

Betrik J. Hutapea, Mesran, Siti Nurhabibah. (2018). Sistem Pendukung Keputusan Pemilihan Kepala Cabang Terbaik Bank Sumut dengan Menerapkan Metode Vikor. KOMIK: Konferensi Nasional Teknologi Informasi dan Komputer, 02(01).

Nunung Ghoniyah dan Masurif. (2011). Peningkatan Karyawan Melalui Kepemimpinan, Lingkungan Kerja dan Komitmen. JDM: Jurnal Dinamika Manajemen, 2(2).

Sri Hindah Pudjihastuti dan Haves Ardhani. (2013). Optimalisasi Kinerja Pegawai Badan Kepegawaian Daerah Kota Semarang. Ekobis, 14(2). 
Ad-Deenar: Jurnal Ekonomi dan Bisnis Islam

Doi: 10.30868/ad.v4i01.755

E-ISSN: 2614-8838 